\title{
Bridge Falsework in Staged Construction of a Prestressed Concrete Beam Bridge
}

\author{
Janusz Hołowaty ${ }^{1}$ and Dariusz Jurkowski ${ }^{2}$ \\ 1. Faculty of Civil Engineering and Architecture, West Pomeranian University of Technology, Szczecin 70-311, Poland \\ 2. PPDM Szczecin, Szczecin 71-063, Poland
}

\begin{abstract}
The formwork and falsework in the construction of twin ribbed slab decks on a multi-span ecological bridge for a dual carriageway are presented. The bridge is situated in a valley plain which is crossed by small rivers and was designed principally with the environment in mind. The bridge length is over $356 \mathrm{~m}$, and the width of the decks is $11.5 \mathrm{~m}$. For the bridge works, a simple conventional falsework system was chosen with steel frames for the supports and steel rolled beams for the decks. The formwork was constructed in solid timber and plywood as multiple-use panels. The falsework was designed in order to build the two 10-span bridge decks in stages. The decks are continuous cast-in-situ prestressed concrete twin rib with spans of $30 \mathrm{~m}, 34 \mathrm{~m}$ and $45 \mathrm{~m}$. An individual falsework system was designed, which was easy to move transversally following completion of each stage for one deck. After finishing each stage, for the second deck, the falsework was dismantled and used again in the next construction fronts. An individual arrangement for the falsework along with timber pilings was used to cross the biggest river. The formwork timber panels were used several times in the multistage bridge construction. The adopted falsework system is very simple, but it allowed the speedy construction of the two decks where there were severe time constraints.
\end{abstract}

Key words: Prestress concrete bridge, continuous bridge, twin rib deck, span-by-span construction, formwork, falsework.

\section{Introduction}

Span-by-span construction of continuous prestressed concrete bridges is one of the most effective cast-in-situ techniques in the case of span lengths between $20 \mathrm{~m}$ and $45 \mathrm{~m}$ [1-3]. Different types of falsework and construction technologies are used depending on the existing constraints and construction potentiality. German contractors have great experience in building span-by-span long girder bridges using typical falsework or self-launching gantries [4-6]. Using a repeated construction cycle enables economic gains at the construction site [1-8].

The paper presents falsework and formwork structures which were developed for a dual superstructure construction for a multi-span ecological viaduct over $356 \mathrm{~m}$ in length on the Stargard Szczeciński bypass in north-western Poland. The

Corresponding author: Janusz Hołowaty, Ph.D., assistant professor, research fields: testing and design of bridges. E-mail: jah@wp.pl. falsework structure and construction stages for the building in segments of two parallel continuous superstructures for a dual carriageway expressway viaduct are given. A simple scaffolding structure included supports from steel heavy-duty props and decks from steel beams. The formwork was designed in the form of timber panels, which enabled multiple use in the progressive span-by-span construction [9].

\section{The Bypass Project and the Ecological Viaduct}

The S10 Expressway Project between Szczecin and Stargard Szczeciński, in north-western Poland, was divided into several sections (contracts). The last section to be constructed was the southern bypass of Stargard Szczeciński (Fig. 1). The total length of the dual-carriageway bypass is $13.5 \mathrm{~km}$. For the project, nine viaducts and two footbridges were constructed. The number of constructed culverts is 61 , due to environmental and wet terrain conditions. Three new 


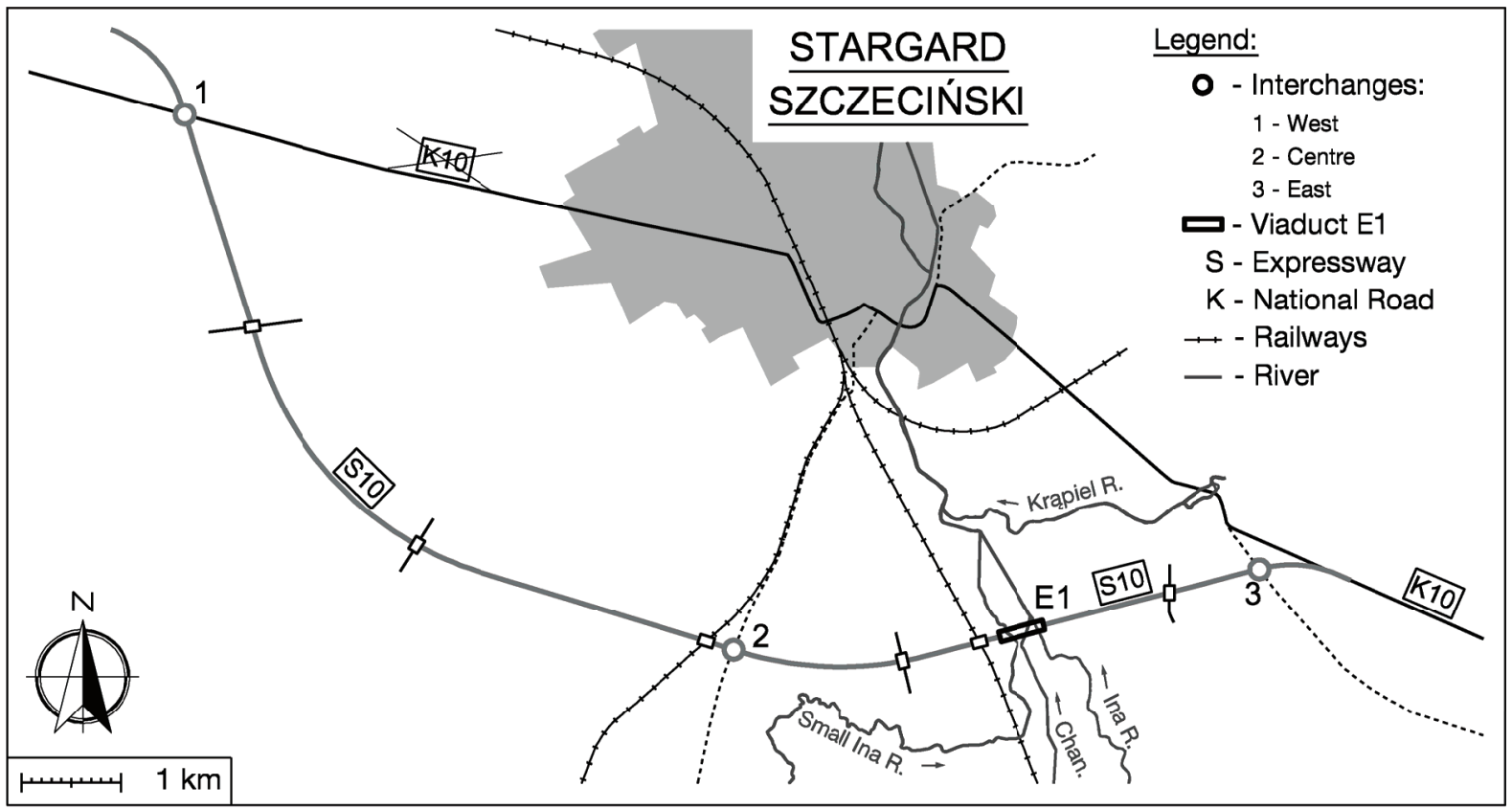

Fig. 1 Site of the project and location of the ecological viaduct.

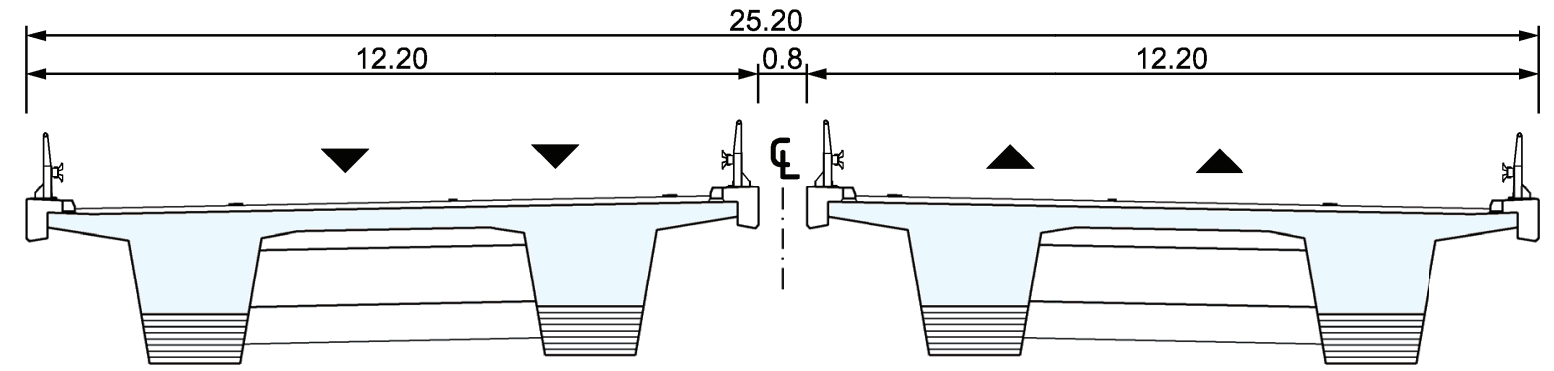

Fig. 2 Ecological viaduct-cross section (units in $\mathbf{m}$ ).

interchanges were constructed. The bypass was opened in December 2009. The total cost was over EUR86,000,000. The new sections of the trunk road will be the future Szczecin-Bydgoszcz S10 Expressway.

The main bridge structure on the bypass is the ecological multi-span viaduct, marked as E1 (Fig. 1). It is located between two interchanges: centre and east, over the Ina River Valley. The structure is for ecological purposes and allows the movement of wild animals under the expressway along the river valley plain. The structure also carries two carriageways of the trunk road over the small Ina River, an drainage channel and some lanes through the fields.

The decks of the viaduct were designed in prestressed concrete as ribbed slabs with two ribs. The decks are separate for each carriageway. A cross section of the viaduct is shown in Fig. 2. Structural concrete of grade C35/45 was used in the decks. The ecological viaduct is a 10-span structure with span length $(30+45+6 \times 34+45+30 \mathrm{~m})$. The total length of the structure is $356.2 \mathrm{~m}$ (Fig. 3).

The internal supports are constructed as two column piers with the external supports massive abutments. The support footings are in reinforced concrete on blinding concrete. The viaduct is of straight alignment with longitudinal grade of $1.2 \%$. The vertical clearance under the bridge is $2.2 \mathrm{~m}$ to $7.6 \mathrm{~m}$.

The viaduct decks have ribs of depth $1.70 \mathrm{~m}$ to $2.50 \mathrm{~m}$. The width of the decks is $11.5 \mathrm{~m}$. The decks were designed to be continuous over the whole length of the bridge. Expansion joints are located only at the abutments. 


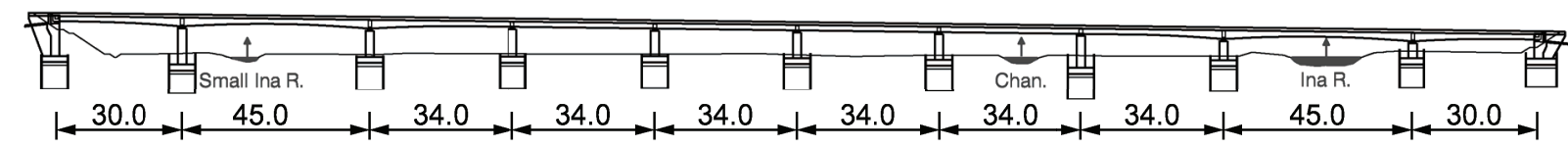

(1)
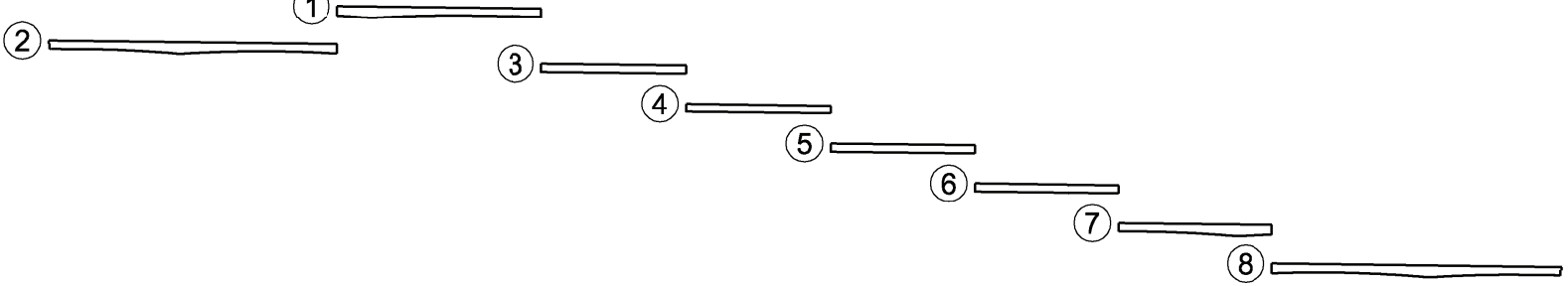

Fig. 3 Ecological viaduct-longitudinal scheme and arrangement of stages for the viaduct deck construction (units in m).

In the viaduct, falsework and formwork design, Polish requirements and codes were applied.

The river valley is located in post-glacial terrain filled with glacial sands covered by peat and organic soils of different depth between $0.4 \mathrm{~m}$ and $2.8 \mathrm{~m}$. This caused problems both in the falsework foundation works and in the transportation of materials and equipment. The soil conditions are typical for West Pomeranian river valleys $[7,8,10]$.

\section{Viaduct Construction Technology}

The viaduct design assumed that the bridge decks would be built in stages; This was followed in construction. The decks were built in eight stages connected with concrete placement and prestressing. Each deck has seven construction joints positioned in areas where the minimum moments and shears occur.

In the first stage of viaduct construction, the casting segment consisted of the third span plus two short cantilevers of the adjoining spans. In the second stage, the casting segment consisted of the first span and the remaining section of the second spans. In the second span, the first construction joint is located. The next spans were built span by span; In one stage, a segment of span length was cast and prestressed. Construction joints in spans with 34-m length were located at about 0.18 of the span length from the piers. In the final Stage 8, the cast segment consisted of part of the ninth span and the entire tenth span. After curing a segment, cables were prestressed, allowing the falsework to be lowered and moved transversally or relocated forward ready for the next span to be built.

The location of parallel decks next to each other allowed the adoption of a simple falsework system with repeatable structure for the construction in stages of succeeding segments in both decks. The falsework and formwork members were used repeatedly. The falsework supports were located on the viaduct pier footings and on temporary foundation pads from precast slabs supported on improved soils (at midspan). Soil improvement for the falsework intermediate supports was made in one stage for all the viaduct spans except those over the Ina River, where timber piling was designed.

\section{Falsework and Formwork}

Conventional falsework for supporting the formwork during the concreting of the viaduct deck sections was taken from a falsework supplier-heavy duty steel supports and HEB (European standard wide flange $H$ ) wide flange rolled beams for the falsework decks. Steel supports (props) were also manufactured from rolled beams. The props were framed with top and bottom steel caps and internally braced with steel rods and pipes. On top of the props, hydraulic presses were installed for the possibility of lowering the falsework after prestressing the bridge segments. Additional steel beams were used as a sub-base to the steel props; These were used to move the falsework transversally. In the majority of the spans, rolled steel beams of grade S355 non-alloy structural steel were used for the falsework decks and props. 
The formwork was designed as timber panels with individual structures adjusted to the span geometry. The formwork structures are shown in Fig. 4. In the panel structures, timber frames covered by plywood were used. The frames were manufactured from timber logs at a timber plant. At the construction site, formwork panels were formed from the timber frames and covered with plywood. Two basic types of frames were used: for the deck with variable depth of $1.70 \mathrm{~m}$ to $2.50 \mathrm{~m}$, and for the deck with constant depth of $1.70 \mathrm{~m}$.

The rolled beams in the falsework decks were of grade S355, so their deflections under the concrete mix load were quite significant. The beam deflections together with falsework deformations and settlements were taken into account in the final formwork camber calculation to obtain the design profile of the viaduct. For lowering the falsework, hydraulic presses located on the heads of heavy duty props were used. Presses with different capacities were employed depending on the vertical reaction on the props.

The falsework scheme for transversal movement and the next relocation in the first stage of the deck construction is shown in Fig. 5. After completing the first and second stages of the north deck (towards Szczecin), the falsework structure for the first three spans was lowered down on hydraulic presses and moved transversally for the south deck (towards Bydgoszcz). The formwork panels were dismantled with a mobile lift. After the first two stages of the south deck were completed, the falsework was dismantled and relocated for the next construction stages of the north deck.

In typical applications of falsework systems which are movable or relocated span by span, the falsework ends are supported on the existing bridge foundations and on the cantilever ends of previously-cast spans. For the construction of the ecological viaduct decks, intermediate falsework supports were also designed at the bridge midspan areas. The intermediate supports had self-bracing members for stability (Figs. 6a and 7a) and were supported on temporary foundations from precast slabs. The location of the falsework intermediate supports was adjusted for the available lengths of rolled steel beams for the falsework decks. The falsework cross sections used are shown in Fig. 6.

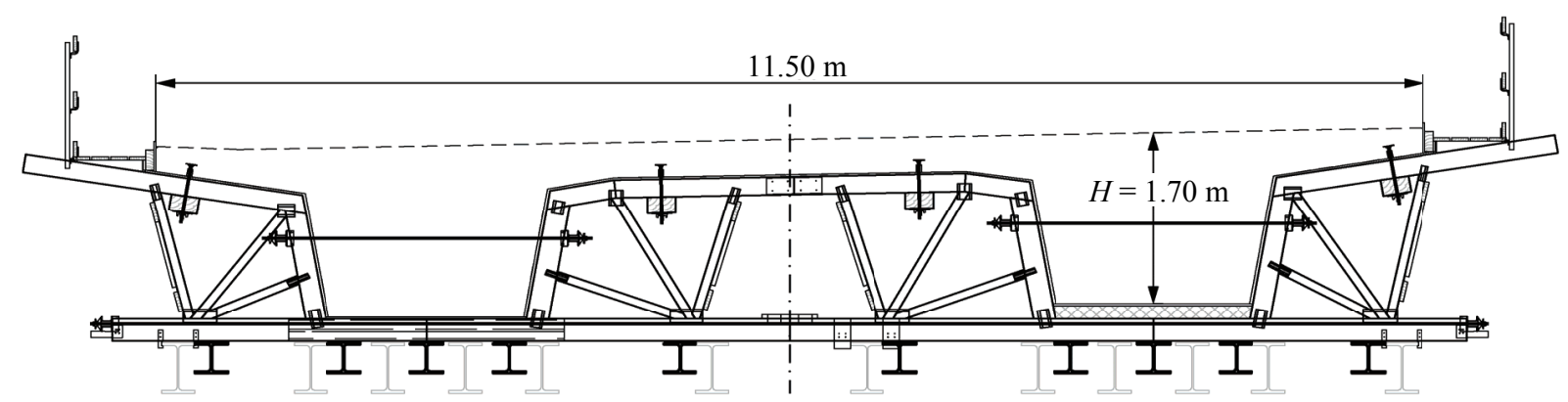

(a)

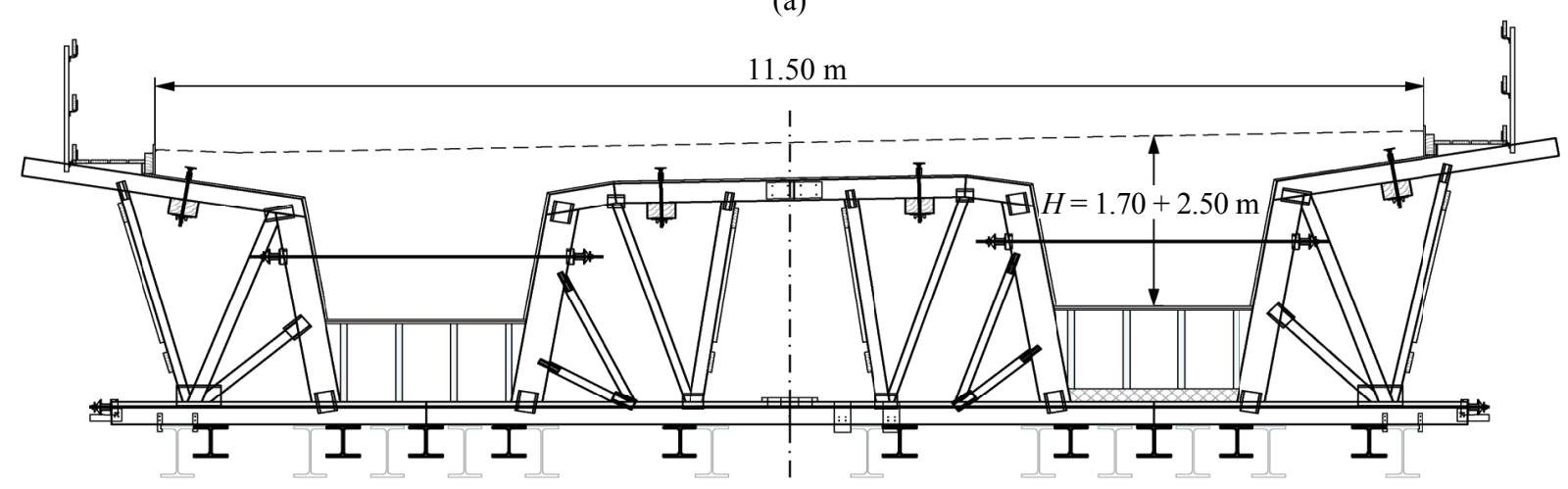

(b)

Fig. 4 The deck formwork: (a) for spans of constant depth of $1.70 \mathrm{~m}$; (b) for span of variable depth between $1.70 \mathrm{~m}$ and $2.50 \mathrm{~m}$. 

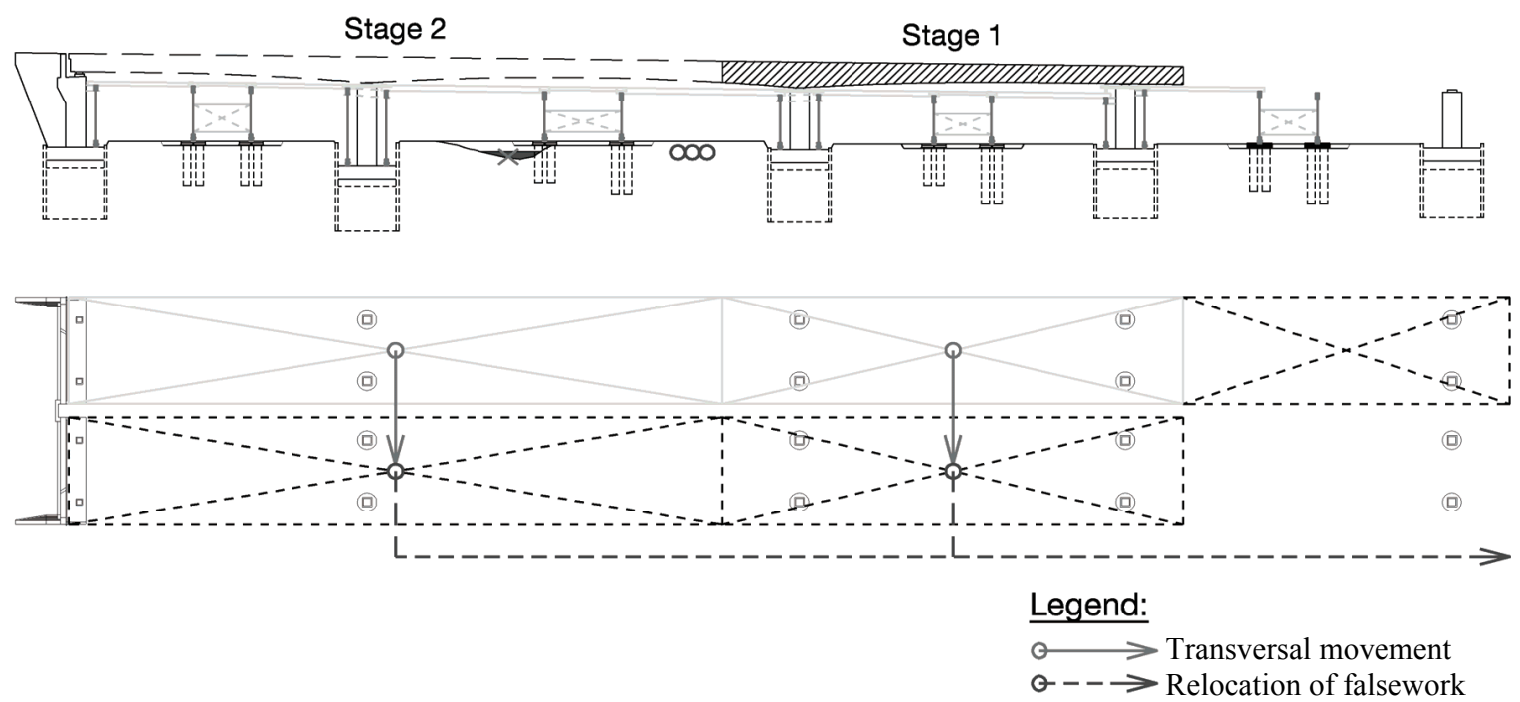

Fig. 5 Scheme of transversal movement and relocation of falsework for Stages 1 and 2 of parallel construction of the two bridge decks.

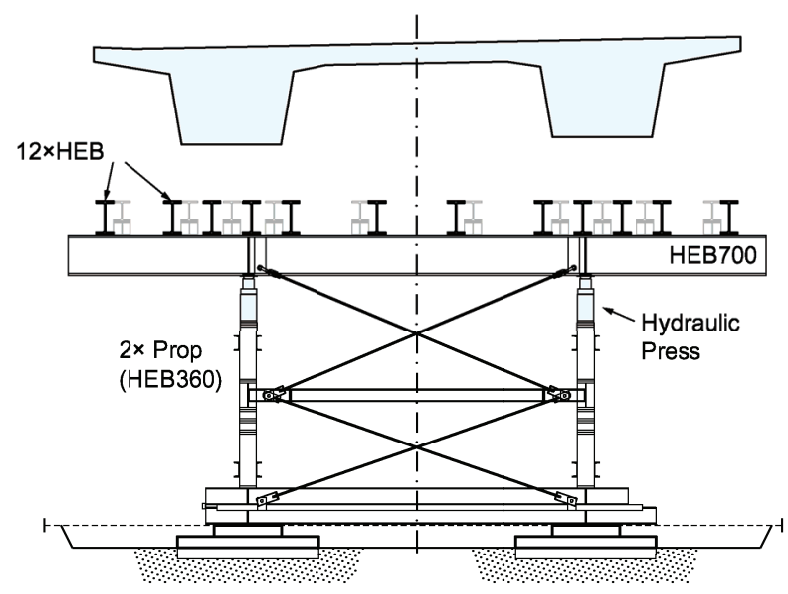

(a)

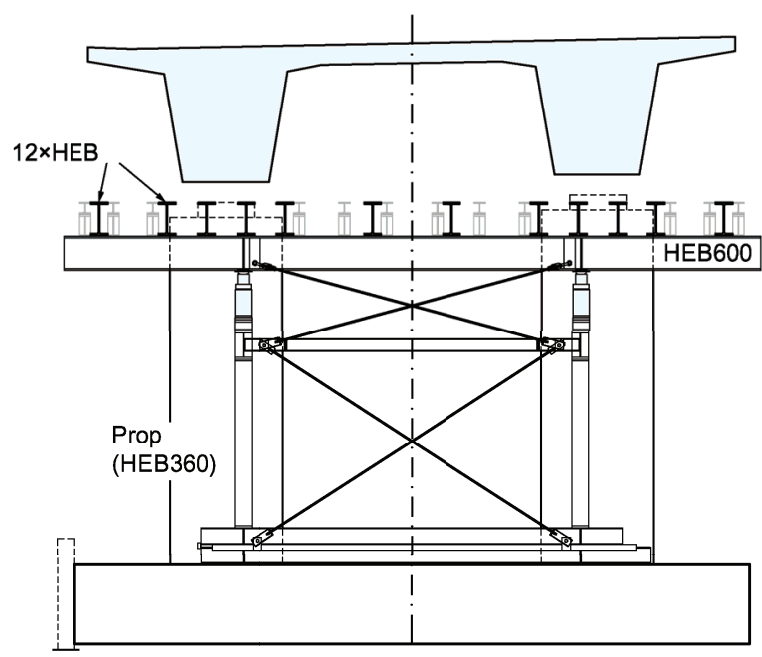

(b)

Fig. 6 Falsework cross sections for the deck with variable depth: (a) at viaduct midspan; (b) near viaduct piers.

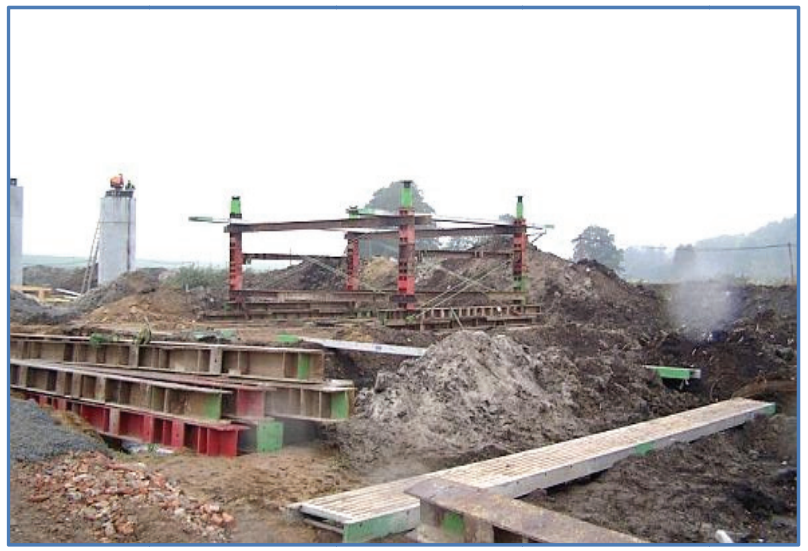

(a)

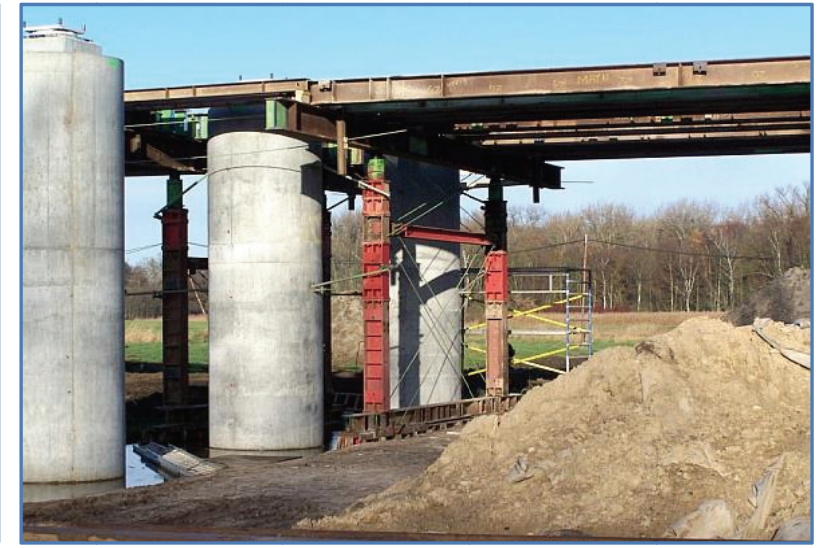

(b)

Fig. 7 Construction of falsework supports: (a) at midspan-two braced frames; (b) near viaduct pier-a simple frame internally braced. 


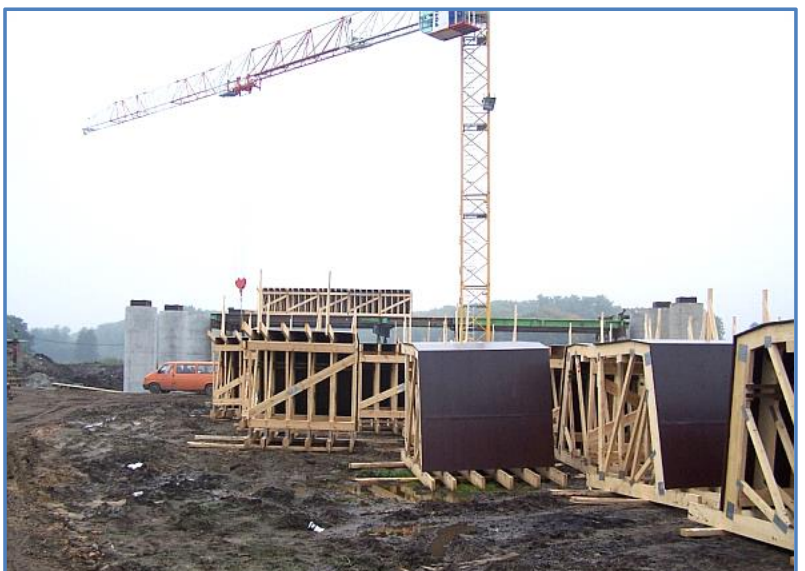

Fig. 8 First part of the falsework for the north deck at initial phase-the first falsework spans and assembly of timber panels.

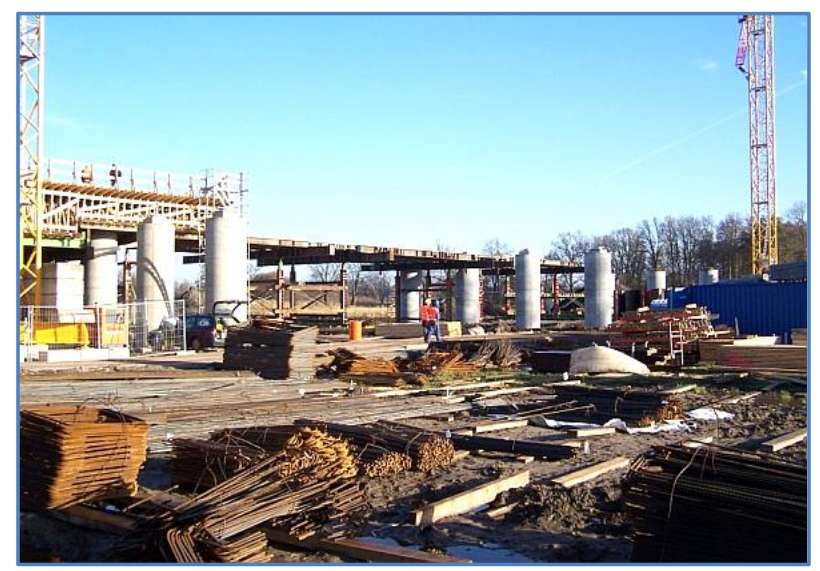

(a)

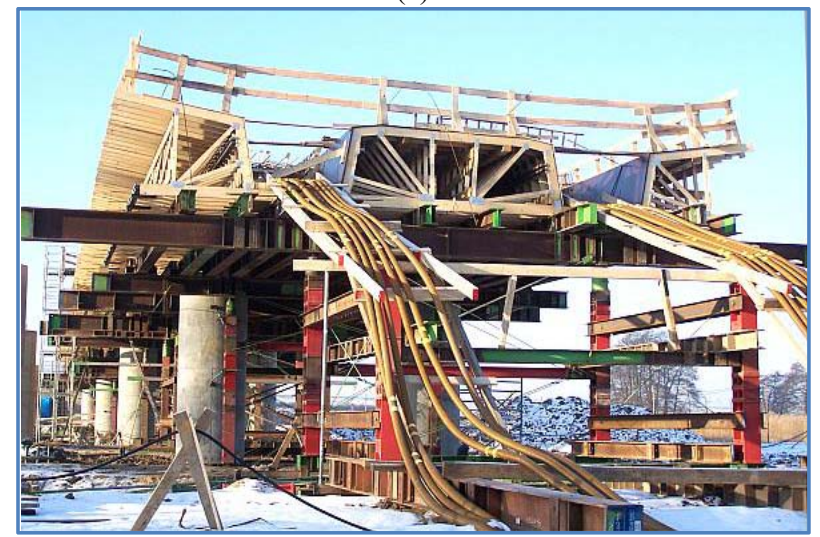

(b)

Fig. 9 Falsework for the next stages of the north deck construction: (a) general view; (b) front view, after timber panel assembly and placement of reinforcement and cables.

A general view of the falsework supports when constructing Stages 1 and 2 is shown in Fig. 7. The prop heads were equipped with hydraulic presses for lowering the falsework. The rolled beams in the falsework decks were supported on top steel caps using centering rods and levering stands. The structure of the lower bases allowed the transversal movement of the falsework. The falsework and formwork assembly for the first segments of the north deck is shown in Fig. 8. In Stages 3 to 7, both decks were built span by span, using timber panels for 1.70-m deck depth.

In order to allow for deformation in the construction joints, additional tie rods were used to clamp the falsework beams at the end of the previously-constructed cantilever sections of the viaduct decks. A view of the following falsework segments for the north deck is shown in Fig. 9. The transversal movement of the falsework was done with the help of small hydraulic jacks (Fig. 10).

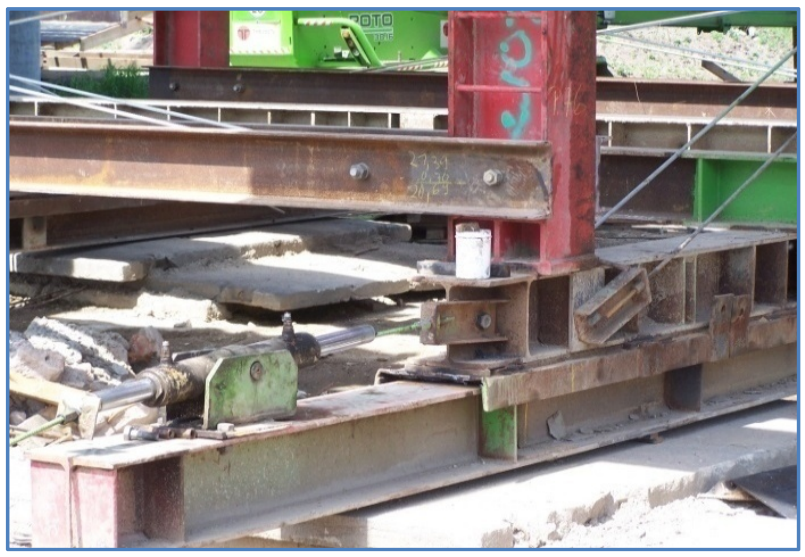

Fig. 10 Transversal movement of the falsework with hydraulic jacks.

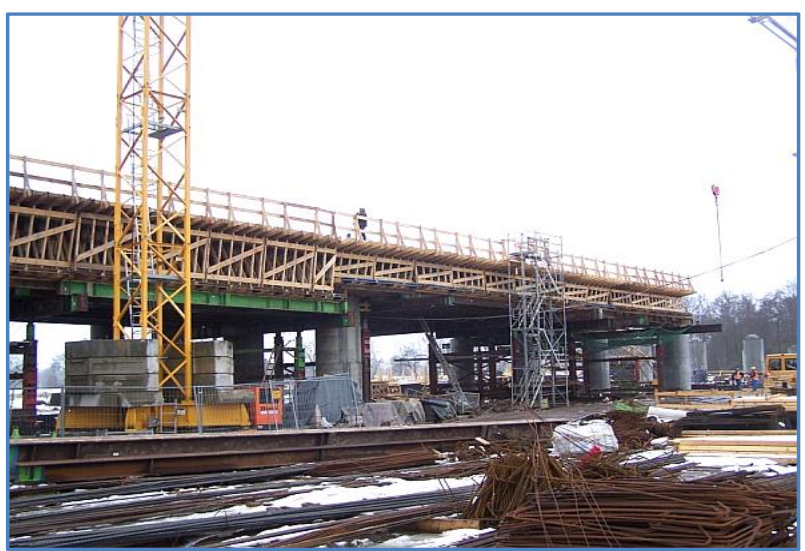

Fig. 11 General view after falsework transversal movement and assembly of timber panels for the south deck: Stages 1 and 3. 


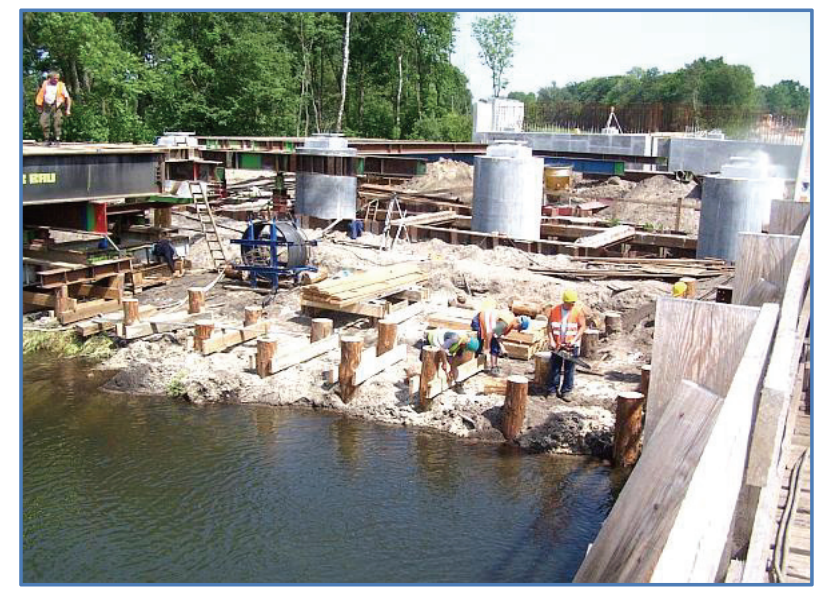

Fig. 12 Last stages of construction: assembly of steel beams for the north deck and timber pilling for the south deck, on the right- the temporary bridge.

A general view of the falsework after transversal movement and formwork assembly for the south deck is shown in Fig. 11. The last sections of the falsework and pile foundation for Stage 8 of the deck construction are shown in Fig. 12.

The introduction of intermediate supports in the falsework assembly allowed the use of shallower rolled beams for the falsework decks and a reduction in the influence of the cast deck segments on bending moment distribution in the cantilever sections of the decks. The design of clamping rods for the falsework beams near the technological joints lowered their deflection and ensured continuity of the formwork in these areas.

Concrete placement and cable prestressing in successive segments of both decks were carried out from December 2008 to August 2009. The main contractor for the viaduct was Bergerbau GmbH-Polish Unit, Wrocław (Poland). The falsework was delivered and assembled by C.O. Weise GmbH \& Co. KG, Dortmund and Berlin (Germany). The authors of the paper prepared the formwork, falsework and timber pilling designs and were responsible for supervising the falsework construction.

\section{Conclusions}

The designed and assembled falsework structures enabled the speedy and effective construction of two parallel viaduct decks in prestressed concrete. The falsework supports and decks featured simplicity and great adaptability for different construction conditions. The technical design for the falsework construction included designs for ground improvement, falsework and formwork. Appropriate cambers were prepared separately for each deck and for each stage of the viaduct construction. The falsework technical details presented in the paper come from a system developed by the falsework supplier. Their simple structure and universality allowed for the speedy design and effective construction in stages of two continuous twin ribbed decks of over $365 \mathrm{~m}$ in length.

\section{References}

[1] Benaim, R. 2008. The Design of Prestressed Concrete Bridges, Concepts and Principles. London and New York: Taylor \& Francis.

[2] Hewson, N. 2012. Prestressed Concrete Bridges, Design and Construction. London: Thomas Telford.

[3] fib (fédérationinternationale du béton). 2009. fib Bulletin 48, Formwork and Falsework for Heavy Construction. Lausanne: $f i b$.

[4] Weidemann, H. 1984. The Construction of Reinforced Concrete and Prestressed Concrete Girder Bridges. Düsseldorf: Werner-Verlag. (in German)

[5] Wittfoht, H. 1984. Building Bridges, History, Technology, Construction. Düsseldorf: Beto-Verlag.

[6] Holst, K. H., and Holst, R. 2004. Reinforced Concrete and Prestressed Concrete Bridges-Design, Construction and Analysis. Berlin: Ernst \& Sohn.

[7] Hołowaty, J. 2009. "Bridge Falsework in Construction of Approach Viaducts for the Regalica Bridge Crossing in Szczecin." Inżynieria i Budownictwo 8: 441-5. (in Polish)

[8] Hołowaty, J. 2013. "Falseworks for Concrete Bridge Construction in Subsidence of Soft Soils in Szczecin." Presented at CCC 2013 - Central European Congress on Concrete Engineering - Concrete Structures in Urban Areas, Wrocław, Poland.

[9] Hołowaty, J., and Jurkowski, D. 2015. "Timber Formwork for Concrete Bridge Construction." Bridges 1: 26-8. (in Polish)

[10] Hołowaty, J. 2013. "Partial Collapse of Bridge Falsework and Salvage Technique." Presneted at 5th ICE (International Conference on Forensic Engineering) 2013: "Informing the Future with Lessons from the Past", London, UK. 